\title{
Digestible threonine for slow-growing broilers: performance, carcass characteristics, intestinal mucin, and duodenal morphometry
}

\section{Noédson de Jesus Beltrão Machado ${ }^{1 *}$, Cristina Amorim Ribeiro de Lima ${ }^{2}$, Ronner Joaquim Mendonça Brasil' , Débora Vaccari Quaresma1', Felipe Dilelis', Ana Paula Pereira da Silva4, Fernando Augusto Curvello}

\footnotetext{
${ }^{1}$ Universidade Federal Rural do Rio de Janeiro, Programa de Pós-graduação em Zootecnia, Seropédica, RJ, Brasil.

${ }^{2}$ Universidade Federal Rural do Rio de Janeiro, Instituto de Zootecnia, Departamento de Nutrição Animal e Pastagens, Seropédica, RJ, Brasil.

${ }^{3}$ Universidade do Estado do Amazonas, Rede Bionorte, Manaus, AM, Brasil.

${ }^{4}$ Universidade Federal Rural do Rio de Janeiro, Instituto de Ciências Exatas, Departamento de Química, Seropédica, RJ, Brasil.

${ }^{5}$ Universidade Federal Rural do Rio de Janeiro, Instituto de Zootecnia, Departamento de Produção Animal, Seropédica, RJ, Brasil.
}

\begin{abstract}
Five experiments were conducted to estimate the digestible threonine requirements of slow-growing broilers: experiment 1, starter phase (days 10 to 28); experiment 2, grower I phase (days 29 to 49); experiment 3, grower II phase (days 50 to 69 ); experiment 4 , finisher phase (days 70 to 84 ); and experiment 5, which was specifically conducted to determine the production of intestinal mucin over two periods (days 50 to 69 and 70 to 84). Different birds were used in all experiments. A completely randomized design with five treatments and four replicates was used. Treatments consisted of increasing the values of digestible threonine in the diet through basal feed supplementation with L-threonine (98.5\%), which was added instead of cornstarch. The following values of digestible threonine were investigated: $0.622,0.697,0.772,0.847$, and $0.922 \%$ in experiment $1 ; 0.586,0.662,0.738,0.814$, and $0.890 \%$ in experiment $2 ; 0.570,0.640,0.71,0.780$, and $0.850 \%$ in experiments 3 and 5; and $0.520,0.595,0.670,0.745$, and $0.820 \%$ in experiments 4 and 5 . The digestible threonine values presented quadratic effects on feed conversion ratio in experiments 1, 2, and 3. Digestible threonine values of 0.628 and $0.609 \%$ resulted in higher villus height and greater duodenal crypt depth, respectively. Digestible threonine values of $0.762,0.767$, and $0.733 \%$ may be recommended for the starter, grower I, and grower II phases, respectively, based on the best feed conversion ratio. In addition, a digestible threonine level of $0.694 \%$ may be recommended for the finisher phase based on the highest production of intestinal mucin.
\end{abstract}

Key Words: amino acid, nutritional requirements, villus

\section{Introduction}

Threonine is considered the third limiting amino acid for broilers fed corn-soybean meal-based diets (Ayasan and Okan, 2006), being an essential amino acid for broilers, and has key functions in the animal body. It is the main component of intestinal mucus, which aids in nutrient digestion and absorption and consists primarily of mucin produced by goblet cells (Smirnov et al., 2006). Threonine may represent up to $40 \%$ of the amino acids that make up these glycoproteins (Abassi et al., 2014).

Received: July 26, 2017

Accepted: November 28, 2017

*Corresponding author: njbmachado@hotmail.com

Copyright (C) 2018 Sociedade Brasileira de Zootecnia. This is an Open Access article distributed under the terms of the Creative Commons Attribution License (http://creativecommons.org/licenses/by/4.0/), which permits unrestricted use, distribution, and reproduction in any medium, provided the original work is properly cited.
Decreased intestinal mucin production can reduce nutrient utilization by minimizing the intestinal mucus layer (Horn et al., 2009).

Threonine also affects animal immune systems ( $\mathrm{Li}$ et al., 2007 ) and may account for 7 to $11 \%$ of all amino acids in immunoglobulins (Sandberg et al., 2007). It participates in the uric acid formation and in protein synthesis (Eftekhari et al., 2015). Deficiencies in digestible threonine may lead to impaired function of the aforementioned organic molecules.

Regarding the feed nutritional values, there is no difference in preceacal amino acid digestibility between fast- and slow-growing broiler strains in soybean cake; thus, the results estimated could be applied to both types of broiler strains (Ganzer et al., 2017).

However, the nutritional requirements may vary according to the growth potential. Most research assessing the nutrient requirements have been conducted using fastgrowing broilers. Ayaşan et al. (2009) concluded that the 
$0.75 \%$ level of threonine maximizes body weight gain in the period from 22 to 42 days of age. Little information is known on the threonine requirements of slow-growing broilers. The CobbSasso150 (Cobb-Vantress, 2008) slowgrowing broiler strain manual recommends total threonine values of $0.90,0.80$, and $0.76 \%$ for the starter, grower, and finisher phases, respectively.

Redbro Plumé is a strain of French origin and reaches an average final weight of $2200 \mathrm{~g}$ between 70 and 80 days, consuming between 5700 and $6300 \mathrm{~g}$ of ration; it has feathered neck, feathers of strong red colour, and black tail (Miranda et al., 2005).

This study aimed to assess the effects of digestible threonine on performance and carcass traits of slow-growing broilers during the starter (days 10 to 28 ), grower I (days 29 to 49), grower II (days 50 to 69), and finisher (days 70 to 84 ) phases; duodenal morphometry in the finisher phase and production of intestinal mucin in the starter, grower II, and finisher phases were assessed.

\section{Material and Methods}

Research on animals was conducted according to the institutional committee on animal use (case no. 23083.011134/2014-02). The experiments were performed in Seropédica, Rio de Janeiro, Brazil (latitude $22^{\circ} 45^{\prime} \mathrm{S}$ and longitude $43^{\circ} 41^{\prime} \mathrm{W}$ ).

A total of 1600 Redbro Plumé male broiler chicks vaccinated against Marek's, Newcastle, and Gumboro diseases were initially purchased for the experiments and housed in a conventional broiler house. The birds remained in the broiler house until they were transported for the experiments and received water and food ad libitum.

Five experiments were conducted from June 29 to September 21, 2015. In experiment 1 (days 10 to 28), 200 broiler chickens with a uniform mean weight were selected and housed in metabolic cages (measuring $0.90 \times$ $0.85 \times 0.40 \mathrm{~m}$ ) to evaluate broiler performance and mucus production in response to increasing levels of digestible threonine. Under each cage, trays covered with plastic were placed to collect excreta and determine intestinal mucin production.

Experiments 2 (grower phase I, from days 29 to 49), 3 (grower phase II, from days 50 to 69), and 4 (finisher phase, from days 70 to 84 ) were conducted to investigate response of performance and carcass characteristics of broilers fed increasing proportions of digestible threonine. The experimental pens in which the birds were housed measured $4 \times 5 \mathrm{~m}$ and contained wood shavings beds, feeders, and water troughs.
Experiment 5 was conducted with different broilers housed during two different age periods (days 50 to 69 and 70 to 84). Initially, 60 broilers of uniform mean weight were selected at 50 days of age and housed in metabolic cages in a similar manner to that mentioned for experiment 1 for total excreta collections and to determine intestinal mucus production. At the end of the experimental period, at 69 days of age, the broilers were removed from the cages, and the cages were sanitized. Then, an additional 60 broilers at 70 days of age were housed in the cages and remained in these locations until 84 days of age to allow for another round of excreta collection and determination of intestinal mucus. Outside the experimental periods, birds were fed reference feeds according to the recommendations of the Brazilian table for poultry and swine (Rostagno et al., 2011).

The lighting programme followed the recommendations of the Normative Instruction Number 46 of the Ministry of Agriculture, Livestock and Food Supply and consisted of $16 \mathrm{~h}$ of light and $8 \mathrm{~h}$ of dark (Brasil, 2011).

The experiments were conducted in a completely randomized design with five treatments and four replicates. Each replicate consisted of 10 chicks in experiment 1, 22 broilers in experiments 2 and 3, 20 broilers in experiment 4, and three broilers in experiment 5 (for each period studied). A total of 200, 440, 440, 400, and 120 birds were used in experiments $1,2,3,4$, and 5 , respectively.

The experimental diets contained increasing proportions of digestible threonine and were obtained by supplementing the basal feed with L-threonine (98.5\%), which was added instead of cornstarch. The treatments were as follows: $0.622,0.697,0.772,0.847$, and $0.922 \%$ digestible threonine in experiment $1 ; 0.586,0.662,0.738$, 0.814 , and $0.890 \%$ digestible threonine in experiment 2 ; $0.570,0.640,0.710,0.780$, and $0.850 \%$ digestible threonine in experiment 3 ; and $0.520,0.595,0.670,0.745$, and $0.820 \%$ digestible threonine in experiment 4 . The treatments studied in experiment 5 were the same experimental diets as in experiment 3 (for grower phase II) and experiment 4 (for the finisher phase) (Table 1).

In all experiments, the basal feed formula was based on corn and soybean meal and met the requirements mentioned by Rostagno et al. (2011). The criterion for determining the feed requirement was the mean body weight of the animals rather than ages as described in the Brazilian table for poultry and swine (Rostagno et al., 2011). The values of available phosphorus and calcium suggested by Pinheiro et al. (2011a, 2011b) were used.

In experiments 1-4, body weight gain (BWG), feed intake (FI), feed conversion ratio (FCR), threonine intake 
(TI), and threonine utilisation efficiency (TUE) were assessed. Threonine intake was calculated by multiplying the mean FI by threonine digestibility, and TUE was assessed by dividing the mean BWG by TI.

At the end of experiments 3, 4, and 5, four broilers per replicate were selected based on the representative mean weight of the replicates; these animals were slaughtered by cervical dislocation, bled, scalded, plucked, and eviscerated. They were then subjected to a pre-cooling process with a 5-min dripping step. The carcasses were weighed and

Table 1 - Ingredient and nutrient compositions of basal diets used in experiments

\begin{tabular}{|c|c|c|c|c|}
\hline \multirow{2}{*}{ Iem } & \multicolumn{4}{|c|}{ Experiment } \\
\hline & 1 & 2 & 3 and 5 & 4 and 5 \\
\hline \multicolumn{5}{|l|}{ Ingredient ( $\mathrm{g} / \mathrm{kg}$ as fed) } \\
\hline Corn grain $(7.73 \% \mathrm{CP})^{1}$ & 658.36 & 695.35 & 709.58 & 749.18 \\
\hline Soybean meal $(46.26 \% \mathrm{CP})^{1}$ & 277.74 & 251.42 & 236.55 & 198.58 \\
\hline Soybean oil & 8.57 & 7.07 & 13.65 & 10.33 \\
\hline Dicalcium phosphate & 15.86 & 10.233 & 12.45 & 12.77 \\
\hline Corn starch & 6.00 & 7.00 & 7.00 & 7.00 \\
\hline Calcitic limestone & 18.69 & 8.42 & 8.43 & 8.47 \\
\hline Common salt & 4.81 & 4.56 & 4.43 & 4.37 \\
\hline DL-methionine & 3.31 & 2.87 & 2.40 & 2.81 \\
\hline L-lysine $\mathrm{HCl}$ & 4.11 & 8.38 & 3.01 & 3.84 \\
\hline Vitamin mixture $^{2}$ & 1.00 & 1.00 & 1.00 & 1.00 \\
\hline Mineral mixture ${ }^{3}$ & 1.00 & 1.00 & 1.00 & 1.00 \\
\hline Choline chloride & 0.55 & 0.50 & 0.40 & 0.40 \\
\hline Butylated hydroxytoluene & - & 0.10 & 0.10 & 0.10 \\
\hline L-tryptophan & - & - & - & 0.15 \\
\hline \multicolumn{5}{|l|}{ Nutritional composition $(\%)^{4}$} \\
\hline Linoleic acid & 1.955 & 1.923 & 2.283 & 2.150 \\
\hline Calcium $^{5}$ & 1.160 & 0.680 & 0.680 & 0.680 \\
\hline Chlorine & 0.340 & 0.326 & 0.318 & 0.315 \\
\hline Metabolizable energy $(\mathrm{kcal} / \mathrm{kg})$ & 2980 & 3050 & 3100 & 3125 \\
\hline Available phosphorus ${ }^{6}$ & 0.394 & 0.325 & 0.325 & 0.325 \\
\hline Digestible leucine & 1.489 & 1.437 & 1.402 & 1.315 \\
\hline Total lysine ${ }^{7}$ & 1.283 & 1.540 & 1.084 & 1.049 \\
\hline Digestible lysine & 1.170 & 1.442 & 0.987 & 0.960 \\
\hline Digestible methionine and cysteine & 0.835 & 0.773 & 0.713 & 0.722 \\
\hline Digestible methionine & 0.582 & 0.529 & 0.477 & 0.502 \\
\hline Potassium & 0.699 & 0.661 & 0.638 & 0.580 \\
\hline Crude protein & 18.58 & 18.00 & 16.93 & 15.60 \\
\hline Sodium & 0.210 & 0.200 & 0.195 & 0.192 \\
\hline Total threonine ${ }^{7}$ & 0.723 & 0.686 & 0.655 & 0.608 \\
\hline Digestible threonine & 0.622 & 0.590 & 0.570 & 0.520 \\
\hline Digestible tryptophan & 0.194 & 0.180 & 0.174 & 0.167 \\
\hline \multicolumn{5}{|c|}{$\begin{array}{l}\text { CP - crude protein. } \\
{ }^{1} \text { Value determined in the food science laboratory of the Animal Science Institute of } \\
\text { the Universidade Federal Rural do Rio de Janeiro. } \\
{ }^{2} \text { Guaranteed analysis (per kg of product): vitamin } \mathrm{A}, 6,000,000 \mathrm{IU} \text {; vitamin } \mathrm{D}_{3} \text {, } \\
2,000,000 \mathrm{IU} \text {; vitamin } \mathrm{E}, 12,000 \mathrm{mg} \text {; vitamin } \mathrm{K}_{3}, 800 \mathrm{mg} \text {; vitamin } \mathrm{B}_{1}, 1,000 \mathrm{mg} \text {; } \\
\text { vitamin } \mathrm{B}_{2}, 4,500 \mathrm{mg} \text {; vitamin } \mathrm{B}_{6}, 1,500 \mathrm{mg} \text {; vitamin } \mathrm{B}_{12}, 12,000 \mathrm{mg} \text {; niacin, } 30,000 \mathrm{mg} \text {; } \\
\text { calcium pantothenate, } 10,000 \mathrm{mg} \text {; folic acid, } 550 \mathrm{mg} \text {; biotin, } 50 \mathrm{~g} \text {; antioxidant, } 5,000 \mathrm{mg} \text {; } \\
\text { excipient q.s., } 1,000 \mathrm{~g} \text {. }\end{array}$} \\
\hline \multicolumn{5}{|c|}{$\begin{array}{l}{ }^{3} \text { Guaranteed analysis (per kg of product): iron (ferrous sulphate), } 60,000 \mathrm{mg} \text {; copper } \\
\text { (copper sulphate), } 13,000 \mathrm{mg} \text {; manganese (manganese sulphate), } 120,000 \mathrm{mg} \text {; zinc } \\
\text { (zinc oxide), } 100,000 \mathrm{mg} \text {; iodine (calcium iodine), } 2,500 \mathrm{mg} \text {; selenium (sodium } \\
\text { selenite), } 500 \mathrm{mg} \text {; excipient q.s., } 1,000 \mathrm{~g} \text {. }\end{array}$} \\
\hline
\end{tabular}

separated into breast, wing, thigh, drumstick, and back sections, which were weighed to assess the yield relative to cold carcass weight.

At the slaughter for experiment 4, two broiler chickens were collected per replicate, and the small intestines were reserved for analysis of duodenal morphometry. After the intestines were sanitized, two samples measuring approximately $5 \mathrm{~cm}$ were collected from the duodenal portion and fixed in formalin solution (5\%). The samples were dehydrated, deparaffinized in xylene, impregnated with resin, sliced to a thickness of $5 \mu \mathrm{m}$ on a microtome, and mounted on slides. The slides were then stained with haematoxylin and eosin and covered with glass cover slips to permit microscopic analysis of villus height and crypt depth. A binocular microscope was used to capture the images and perform the measurements; 30 measurements per replicate were obtained. Villus height was measured from the basal area, which coincided with the upper portion of the crypt, to the apex; the crypts were measured from the base to the crypt, which indicated a villus transition area. Measurements were expressed in $\mu \mathrm{m}$.

Quantification of crude intestinal mucin production was performed by analysis of excreta from the birds, in experiments 1 and 5. Excreta was collected twice daily $(8.00$ and $16.00 \mathrm{~h}$ ) during the last three days in each experimental period. The method proposed by Horn et al. (2009) was used to perform the analysis of crude mucin. For each sample, $3 \mathrm{~g}$ of excreta was placed in a plastic centrifuge tube, and $20 \mathrm{~mL}$ of chilled $\left(4{ }^{\circ} \mathrm{C}\right) \mathrm{NaCl}$ solution $(0.15 \mathrm{M} \mathrm{NaCl}$, $0.02 \mathrm{M} \mathrm{NaN}_{3}$ ) were added. The solution was homogenized for $30 \mathrm{~s}$ and centrifuged at $12,000 \mathrm{~g}$ for $20 \mathrm{~min}$ at $4{ }^{\circ} \mathrm{C}$. The soluble supernatant was decanted into a pre-weighed $50-\mathrm{mL}$ tube. Then, $15 \mathrm{~mL}$ of absolute ethanol solution was added to the supernatant, and the mucin proteins were extracted overnight at $-20{ }^{\circ} \mathrm{C}$. The mixture was centrifuged for $10 \mathrm{~min}$ at $4{ }^{\circ} \mathrm{C}$, and the sediment retained the mucin. The pelleted mucin was washed in a mixture of $10 \mathrm{~mL}$ of $\mathrm{NaCl}$ $\left(0.15 \mathrm{M} \mathrm{NaCl}, 0.02 \mathrm{M} \mathrm{NaN}_{3}\right)$ and $15 \mathrm{~mL}$ of absolute ethanol overnight at $-20^{\circ} \mathrm{C}$. The mixture was then centrifuged, and the sediment was washed until a clear supernatant was obtained. The supernatant was removed by aspiration, and the pellet was weighed to assess the crude mucin yield.

The data were analyzed using the statistical program SISVAR (Analysis System of Variance) (Ferreira, 2011), considering a P-value of 0.05 to be significant. Experimental responses to the values of digestible threonine were studied by regression analysis, and estimates of nutritional requirements were established, when possible, by studying the quadratic model. 


\section{Results}

Digestible threonine values exerted quadratic effects on BWG $(\mathrm{P}=0.001)$ and FCR $(\mathrm{P}=0.021)$ and linear effects on FI $(\mathrm{P}=0.042)$ and TI and TUE $(\mathrm{P}=0.001)$ (Table 2$)$. Increased $\mathrm{BWG}$, which corresponded to a maximum gain estimate of $671.26 \mathrm{~g}$, was estimated to require $0.716 \%$ digestible threonine. The required estimate for FCR was $0.762 \%$, with an intake corresponding to a digestible threonine:lysine ratio of $65.12 \%$.

Table 2 - Body weight gain (BWG), feed intake (FI), feed conversion ratio (FCR), threonine intake (TI), and threonine utilisation efficiency (TUE) of slowgrowing broilers in experiments $1,2,3$, and 4

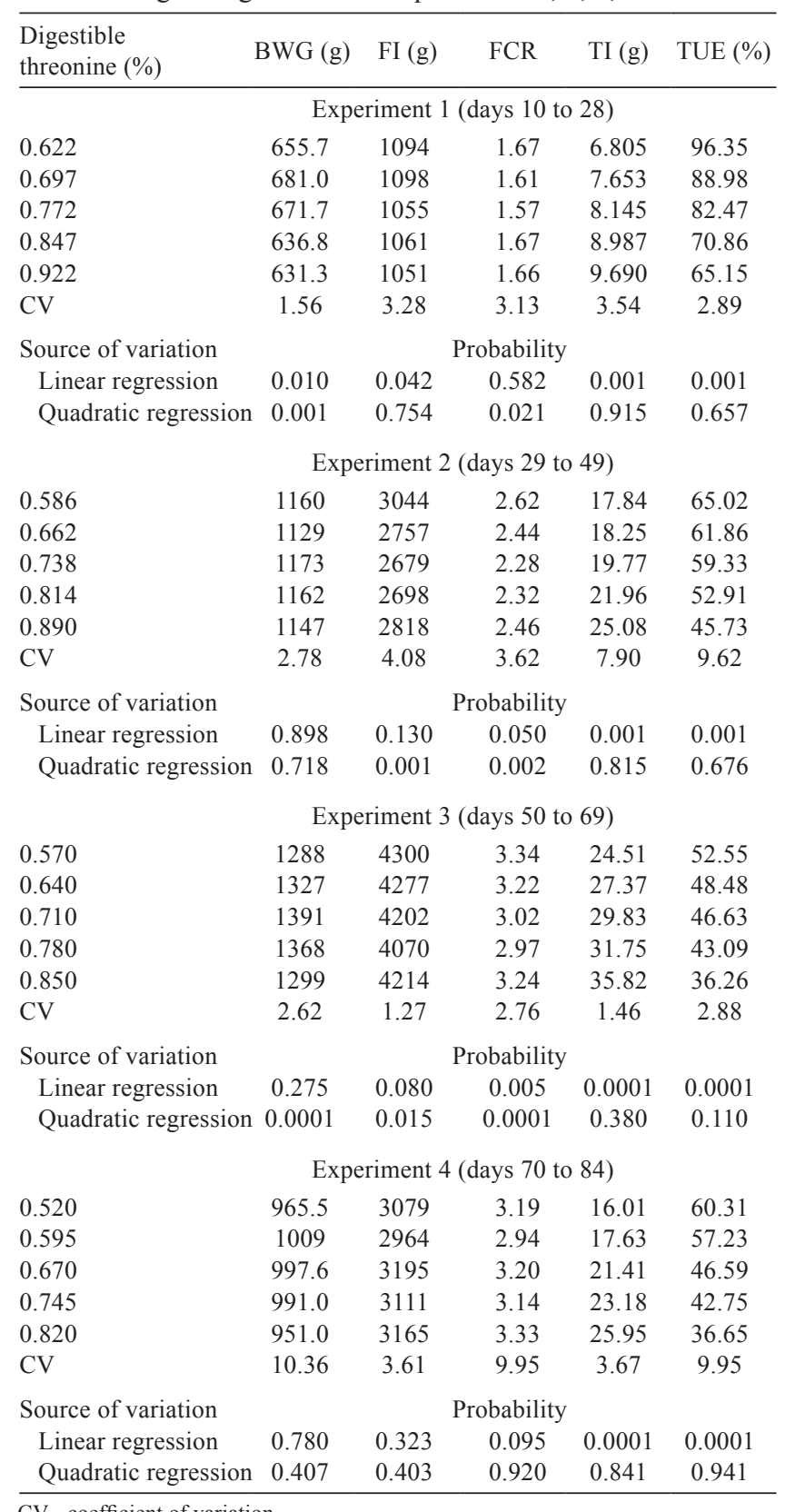

$\mathrm{CV}$ - coefficient of variation.
Threonine had a significant quadratic effect $(\mathrm{P}=0.001)$ on mucin production, with a $0.775 \%$ requirement for maximum mucin production, which corresponded to an intestinal mucin production of $524.1 \mathrm{~g} / \mathrm{kg}$ excreta (Table 3).

We verified quadratic effects for FI $(\mathrm{P}=0.001)$ and FCR $(\mathrm{P}=0.002)$, but linear effects were observed for TI $(\mathrm{P}=0.001)$ and TUE $(\mathrm{P}=0.001)$ (Table 2$). \mathrm{A} 0.767 \%$ requirement was estimated for the minimum FI and FCR according to the quadratic model. The dietary level of digestible threonine had no effect on cut yields except for the back, which showed a quadratic effect $(\mathrm{P}=0.030)$ with an estimated requirement of $0.738 \%$ digestible threonine (Table 4).

In experiment 3 , BWG $(\mathrm{P}=0.0001)$, FI $(\mathrm{P}=0.015)$, and FCR $(\mathrm{P}=0.0001)$ were significantly affected by the dietary threonine level (Table 2). The requirement for digestible threonine estimated for BWG was $0.720 \%$, which corresponded to a gain of approximately $1378 \mathrm{~g}$ during the experimental period. Conversely, the requirement for digestible threonine estimated for the lowest FI was $0.777 \%$. The requirement for FCR was estimated at $0.733 \%$. Yields of breast, thigh and drumstick, and wing showed linear effects $(P=0.001)$. The negative linear effect on breast yield showed that the yield of that cut decreased with increasing dietary values of digestible threonine (Table 4).

No digestible threonine effects on BWG, FI, or FCR $(\mathrm{P}>0.05)$ were observed (Table 2). Threonine values affected only thigh and drumstick yields $(\mathrm{P}=0.022)$, which showed a linear effect (Table 4).

Villus height $(\mathrm{P}=0.001)$, crypt depth $(\mathrm{P}=0.002)$, and villus height:crypt depth ratio $(\mathrm{P}=0.001)$ were affected by the digestible threonine values tested (Table 5). The quadratic effect observed in the duodenal morphometry study of villus height, crypt depth, and duodenal villus height:crypt depth ratio yielded an estimation of the requirement for the highest villus height of $0.628 \%$

Table 3 - Intestinal mucin production of slow-growing broilers in the starter phase (experiment 1)

\begin{tabular}{lc}
\hline Digestible threonine $(\%)$ & Mucin $(\mathrm{g} / \mathrm{kg}$ excreta) \\
\hline 0.622 & 368.20 \\
0.697 & 513.20 \\
0.772 & 489.50 \\
0.847 & 510.30 \\
0.922 & 387.10 \\
$\mathrm{CV}$ & 4.80 \\
Source of variation & \\
$\quad$ Linear regression & 0.062 \\
Quadratic regression & 0.001 \\
\hline
\end{tabular}

$\mathrm{CV}$ - coefficient of variation. 
digestible threonine, which provided a maximum villus height of $1423.44 \mu \mathrm{m}$. The greatest crypt depth was estimated to require $0.609 \%$ digestible threonine, which resulted in a maximum crypt depth of $235.54 \mu \mathrm{m}$.

Threonine had a significant quadratic effect $(\mathrm{P}=0.001)$ on mucin production. The increase in dietary values

Table 4 - Carcass yield and cuts of slow-growing broilers slaughtered at 50,70, and 85 days of age in experiment 2,3 , and 4 , respectively

\begin{tabular}{|c|c|c|c|c|c|}
\hline $\begin{array}{l}\text { Digestible } \\
\text { threonine }(\%)\end{array}$ & $\begin{array}{c}\text { Carcass } \\
(\%)\end{array}$ & $\begin{array}{c}\text { Breast } \\
(\%)\end{array}$ & $\begin{array}{l}\text { TD } \\
(\%)\end{array}$ & $\begin{array}{l}\text { Wing } \\
(\%)\end{array}$ & $\begin{array}{c}\text { Back } \\
(\%)\end{array}$ \\
\hline & \multicolumn{5}{|c|}{ Slaughter at 50 days } \\
\hline 0.586 & 63.66 & 29.54 & 34.28 & 13.50 & 22.71 \\
\hline 0.662 & 64.13 & 31.03 & 33.50 & 13.69 & 21.86 \\
\hline 0.738 & 64.31 & 30.52 & 34.00 & 13.73 & 21.78 \\
\hline 0.814 & 64.65 & 29.56 & 34.41 & 13.84 & 22.17 \\
\hline 0.890 & 64.26 & 30.02 & 34.24 & 13.51 & 22.58 \\
\hline $\mathrm{CV}$ & 2.43 & 6.10 & 5.02 & 4.16 & 6.46 \\
\hline \multicolumn{2}{|l|}{ Source of variation } & \multicolumn{3}{|c|}{ Probability } & \\
\hline Linear regression & 0.437 & 0.243 & 0.221 & 0.220 & 0.142 \\
\hline \multirow[t]{2}{*}{ Quadratic regression } & 0.094 & 0.187 & 0.372 & 0.415 & 0.030 \\
\hline & \multicolumn{5}{|c|}{ Slaughter at 70 days } \\
\hline 0.570 & 66.08 & 30.24 & 33.54 & 13.04 & 22.72 \\
\hline 0.640 & 66.04 & 30.00 & 33.62 & 13.20 & 22.01 \\
\hline 0.710 & 66.58 & 30.40 & 33.50 & 13.53 & 22.48 \\
\hline 0.780 & 66.28 & 29.96 & 33.98 & 13.62 & 23.56 \\
\hline 0.850 & 64.12 & 30.31 & 34.83 & 14.43 & 22.90 \\
\hline $\mathrm{CV}$ & 5.75 & 4.48 & 5.63 & 7.22 & 7.63 \\
\hline \multicolumn{2}{|l|}{ Source of variation } & \multicolumn{3}{|c|}{ Probability } & \\
\hline Linear regression & 0.225 & 0.005 & 0.027 & 0.001 & 0.760 \\
\hline \multirow[t]{2}{*}{ Quadratic regression } & 0.157 & 0.123 & 0.432 & 0.140 & 0.270 \\
\hline & \multicolumn{5}{|c|}{ Slaughter at 85 days } \\
\hline 0.520 & 68.69 & 29.23 & 34.66 & 13.13 & 23.00 \\
\hline 0.595 & 67.75 & 29.28 & 34.49 & 13.39 & 22.88 \\
\hline 0.670 & 68.71 & 29.70 & 34.03 & 12.80 & 23.48 \\
\hline 0.745 & 68.43 & 30.05 & 34.09 & 13.36 & 22.53 \\
\hline 0.820 & 68.89 & 29.34 & 33.76 & 13.49 & 23.40 \\
\hline $\mathrm{CV}$ & 3.24 & 6.15 & 4.41 & 6.31 & 8.01 \\
\hline \multicolumn{2}{|l|}{ Source of variation } & \multicolumn{3}{|c|}{ Probability } & \\
\hline Linear regression & 0.547 & 0.460 & 0.022 & 0.356 & 0.818 \\
\hline Quadratic regression & 0.453 & 0.338 & 0.130 & 0.226 & 0.802 \\
\hline
\end{tabular}

TD - thigh and drumstick; CV - coefficient of variation.

Table 5 - Villus height, crypt depth, and villus height:crypt depth ratio of the duodenal mucosa of slow-growing broilers (experiment 4)

\begin{tabular}{lccc}
\hline Digestible threonine $(\%)$ & $\begin{array}{c}\text { Villus height } \\
(\mu \mathrm{m})\end{array}$ & $\begin{array}{c}\text { Crypt depth } \\
(\mu \mathrm{m})\end{array}$ & $\begin{array}{c}\text { Villus:crypt } \\
\text { ratio }(\mu \mathrm{m})\end{array}$ \\
\hline 0.520 & 1361.47 & 232.14 & 5.86 \\
0.595 & 1398.69 & 231.94 & 6.03 \\
0.670 & 1408.48 & 232.94 & 6.05 \\
0.745 & 1365.42 & 227.58 & 6.00 \\
0.820 & 1190.27 & 205.24 & 5.80 \\
CV & 9.63 & 9.98 & 9.10 \\
Source of variation & & Probability & \\
Linear regression & 0.064 & 0.081 & 0.072 \\
Quadratic regression & 0.001 & 0.002 & 0.002 \\
\hline
\end{tabular}

$\mathrm{CV}$ - coefficient of variation. of digestible threonine resulted in increased intestinal production of crude mucin, up to a maximum at $0.747 \%$ (Table 6) digestible threonine; at higher values of digestible threonine, mucin production decreased. The requirement estimate corresponds to a production of $415.4 \mathrm{~g} / \mathrm{kg}$ excreta of intestinal crude mucin during grower phase II. There was a significant quadratic effect of dietary threonine on intestinal mucin production in the finisher phase, with an estimated $0.694 \%$ (Table 6) requirement of digestible threonine for the maximum production; this resulted in production of $410.2 \mathrm{~g}$ mucin $/ \mathrm{kg}$ excreta.

\section{Discussion}

In experiment 1 , the determined threonine requirements $(0.716 \%$ for $\mathrm{BWG}$ and $0.762 \%$ for $\mathrm{FCR})$ are close to the requirement of $0.78 \%$ digestible threonine that has been reported for slow-growing broilers (Cobb-Vantress, 2008), considering a similar total threonine requirement $(0.90 \%$ recommended in the handbook) for digestible threonine in a corn-soybean meal-based diet and the digestibility coefficients of threonine reported by Rostagno et al. (2011).

The production of intestinal mucin ranged from 368.20 to $513.20 \mathrm{~g} / \mathrm{kg}$ excreta. These values are close to those observed by Horn et al., (2009), who found values ranging from 342 to $382 \mathrm{~g}$ of mucin $/ \mathrm{kg}$ excreta and below the values observed by Ospina-Rojas et al. (2013), who found from 597 to $611 \mathrm{~g}$ of mucin/ $\mathrm{kg}$ excreta.

Table 6 - Intestinal mucin production of slow-growing broilers (experiment 5)

\begin{tabular}{lc}
\hline Digestible threonine $(\%)$ & Mucin $(\mathrm{g} / \mathrm{kg}$ excreta) \\
\hline \multicolumn{2}{c}{ Grower phase II (days 50 to 69$)$} \\
0.570 & 321.20 \\
0.640 & 359.10 \\
0.710 & 426.60 \\
0.780 & 410.30 \\
0.850 & 380.40 \\
CV & 5.20
\end{tabular}

Source of variation

Linear regression $\quad 0.081$

Quadratic regression $\quad 0.001$

\begin{tabular}{lc}
\multicolumn{2}{c}{ Finishing phase (days 70 to 84$)$} \\
0.520 & 355.20 \\
0.595 & 389.40 \\
0.670 & 418.60 \\
0.745 & 396.00 \\
0.820 & 385.10 \\
$\mathrm{CV}$ & 4.12 \\
Source of variation & \\
$\quad$ Linear regression & 0.072 \\
Quadratic regression & 0.001 \\
\hline
\end{tabular}

$\mathrm{CV}$ - coefficient of variation. 
In experiments 2 and 3, with the increase in the digestible threonine values, FI decreased to a minimum and then increased. This may be related to the gradual improvement in the relationship between threonine and other essential amino acids. A physiological explanation for the increased intake observed with the increase in dietary threonine values would be a biological adjustment to meet the amino acid requirements and possible worsening of this relationship upon the increase in dietary digestible threonine (Conhalato et al., 1999). A similar effect was reported by Toledo et al. (2007), when studying the effect of lysine on the performance of broilers of conventional lines.

The estimated digestible threonine requirements for FCR $(0.767 \%$ in experiment 2 and $0.733 \%$ in experiment 3 ) differ from the recommendation of the Nutritional Requirements for Poultry (NRC, 1994) of $0.74 \%$ total threonine during 22 to 42 days of age for broilers and from the results reported by authors who studied threonine requirements of conventional genetic lines (Duarte et al., 2012). This may be explained by the way in which the amino acid requirements are expressed in broilers (as a percentage) and by the lines compared. Conventional lines require nearly double the amount of amino acids required by slow-growing poultry; however, this difference is suppressed when observing the daily FI of broilers of conventional genetic lines (Baker and Han, 1991). This shows that the requirements of slow-growing broilers, expressed as a percentage, may be higher than those of broilers from conventional lines due to their lower daily intake.

It is noteworthy that the increase in digestible threonine led to a decrease in the breast meat yield and an increase in the thigh and drumstick yield in experiment 3. Rezaeipour and Gazani (2014), studying the effects of feed form and feed particle size with dietary L- threonine supplementation in fast-growing broilers, observed that breast and thigh yields were not affected by treatments used. This suggests that more detailed observations of the specificities of slowgrowing lines with respect to the effect of this amino acid on meat cuts should be made. The interactions among threonine, lysine, and methionine can also optimize the accumulation of meat (Abudabos and Aljumaah, 2012).

In all experiments, increased digestible threonine resulted in increased TI and decreased TUE. The increased TI resulted from the increased values of feed and not from FI effects, which corroborated the findings of Corzo et al. (2007) and Mehri et al. (2010).

The findings of this study indicated that threonine has significant effects on intestinal villi, crypt depth, and intestinal mucin production. The values found for villus height are similar to those reported by Najafi et al. (2017), who studied dietary levels of threonine and found the height of villi in the duodenum ranging from 1350.33 to $1551.67 \mu \mathrm{m}$, and below the values found by Ospina-Rojas et al. (2013), who identified a maximum value of $1782 \mu \mathrm{m}$ for villus height in the duodenum.

The results indicated that $0.628 \%$ digestible threonine is optimal for greater villi height. This effect may be due primarily to the direct effect of threonine on the surface area of the intestinal mucosa because threonine has higher activity in mucosal cells than does lysine or methionine (Sadrzadeh et al., 2015). Furthermore, in viscera tissues, which are drained by the portal system, threonine metabolism is higher than that of other essential amino acids (Schaart et al., 2005). Increased digestible threonine values may provide an adequate supply of this amino acid and contribute to high turnover of the intestinal mucosa (Abassi et al., 2014). Horn et al. (2009) postulated that threonine deficiency reduces intestinal protein synthesis, thereby preventing proper maintenance of the mucosa.

According to Chee et al. (2010), Rezaeipour et al. (2012), and Zaefarian et al. (2008), who observed decreased villus heights in animals with threonine deficiencies, feeds with limited threonine content results in lower villi size. Chen et al. (2016) stated that additional supplementation with L-threonine improved the intestinal morphology of broilers; this was shown by increased intestinal villus height and an increased villus height:crypt depth ratio. After the requirements for maximal villus height were met, the results showed no further increase in these parameters, which corroborated the findings of Jazideh et al. (2014), who concluded that excess threonine levels have no effect on these structures once the threonine requirements for adequate intestinal cell function are met.

The analysis of intestinal mucin production in experiments 1 and 5 showed that threonine has significant effects on mucin production and permitted the identification of requirements for maximum mucin production. Considering that increased intestinal mucin production is associated with improved nutrient use (Horn et al., 2009), identifying the conditions required for maximum production of this glycoprotein is important to ensure an intestinal environment that is protective and has adequate selectivity for optimal nutrition and animal performance.

Intestinal mucin production is very dynamic and depends on several chemical and biochemical factors. Thus, the observed gradual increase in mucin production with increasing dietary threonine values may be related to 
Table 7 - Summary of threonine requirements for slow-growing broilers

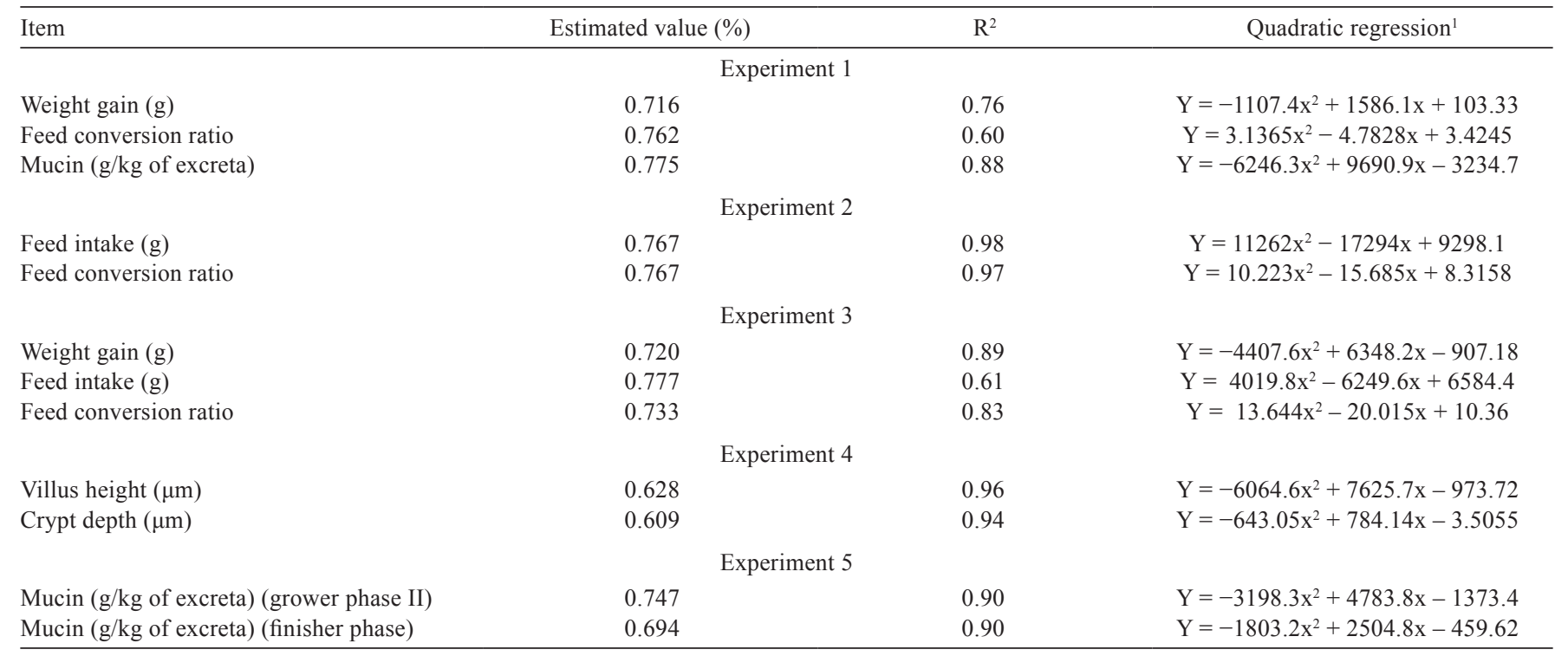

${ }^{1}$ Significant regression $(\mathrm{P}<0.05)$.

the deficiency of this amino acid in limiting diets, which could inhibit the production of mucin glycoprotein by goblet cells. Although the mechanism by which threonine deficiency occurs is not completely understood, this amino acid is known to be essential for mucin structure (Horn et al., 2009).

Increased mucin values similar to those observed in this study after an increase in digestible threonine were also observed by Horn et al. (2009) and Ospina-Rojas et al. (2013), who concluded that threonine affects mucin production. After meeting the threonine requirements for maximum production, further increases in threonine values resulted in decreased mucin production. These results indicated that the effects of excess dietary values of the current required amounts should be further studied.

The results presented here show that the threonine requirements estimated for optimal mucin production were higher than the requirements estimated for BWG. This may be explained by the fact that threonine is of great importance in tissues of the small intestine (Hamard et al., 2007). Furthermore, this amino acid is primarily used for intestinal protein synthesis after absorption by the animal body (Kim et al., 2007); in addition, the composition of this mucus is fundamental in the digestion and absorption of nutrients (Horn et al., 2009). Therefore, the adequate supply of threonine can ensure an optimal secretion of intestinal mucus, which will contribute to a better digestibility of nutrients, directly influencing animal performance.

Thus, research studies that assess only performance parameters may underestimate the threonine requirement.
The study of the quadratic model obtained the digestible threonine requirements for all experiments with their respective determination coefficients and equations (Table 7).

\section{Conclusions}

Threonine is directly related to the maintenance of intestinal mucosa integrity and to intestinal mucin production. These parameters should be considered when estimating nutritional requirements. Values of $0.762,0.767$, and $0.733 \%$ digestible threonine may be recommended for the starter, grower I, and grower II phases, respectively, based on the best feed conversion ratio. A value of $0.694 \%$ digestible threonine may be estimated for the finisher phase based on the adequate production of intestinal mucin. The threonine values estimated for an optimal profile with lysine values lead to a digestible threonine:lysine ratio of $76.06,53.19$, and $74.26 \%$ for the starter, grower I, and grower II phases, respectively, for the best FCR and a ratio of $72.29 \%$ for the finisher growth phase, which is estimated for adequate production of intestinal mucin.

\section{References}

Abassi, M. A.; Mahdavi, A. H.; Samie, H. A. and Jahanian, R. 2014. Effects of different levels of dietary crude protein and threonine on performance, humoral immune responses and intestinal morphology of broiler chicks. Revista Brasileira de Ciência Avícola 16:35-44. 
Abudabos, A. and Aljumaah, R. 2012. Broiler response to reduced protein and energy diets supplemented with lysine, methionine and threonine. Journal Poultry Science 49:101-105.

Ayasan, T. and Okan, F. 2006. Determination of threonine requirements of female broiler chicks in starter period. Journal of the Faculty of Agriculture 21:41-48

Ayaşan, T.; Okan, F. and Hizli, H. 2009. Threonine requirement of broilers from 22 to 42 days. International Journal of Poultry Science 8:862-865.

Baker, D. H and Han, Y. 1991. Lysine requeriments of fast and slow growing broiler chicks. Poultry Science 70:2108-2114.

Brasil. Ministério da Agricultura, Pecuária e Abastecimento. 2011. Instrução Normativa $\mathrm{N}^{\circ} 46$, de 6 de outubro de 2011. Dispõe sobre regulamento técnico para os sistemas orgânicos de produção, bem como as listas de substâncias e práticas permitidas para uso nos sistemas orgânicos de produção. Brasília, DF, 2011. Available at: <http://www. agricultura.gov.br/assuntos/sustentabilidade/organicos/produtosfitossanitarios/IN46.2011alteradapelaIN17.2014epelaIN35.2017.pdf > . Accessed on: Mar. 10, 2016.

Chee, S. H.; Iji, P. A.; Choct, M.; Mikkelsen, L. L. and Kocher, A. 2010. Functional interactions of manno-oligosaccharides with dietary threonine on chicken gastrointestinal tract. I. Growth performance and mucin dynamics. British Poultry Science 51:658-666.

Chen, Y. P.; Cheng, Y. F.; Li, X. H.; Yang, W. L.; Wen, C.; Zhuang, S. and Zhou, Y. M. 2016. Effects of threonine supplementation on the growth performance, immunity, oxidative status, intestinal integrity, and barrier function of broilers at the early age. Poultry Science 96:405-413.

Cobb-Vantress. 2008. Cobb Sasso150: Broiler Performance \& Nutrition. Supplement. 1 ed. Coob Internacional, Arkansas, US.

Conhalato, G. S.; Donzele, J. L.; Albino, L. F. T.; Oliveira, R. F. M. and Fontes, D. O. 1999. Níveis de lisina digestível para frangos de corte machos na fase de 22 a 42 dias de idade. Revista Brasileira de Zootecnia 28:98-104.

Corzo, A.; Kidd, M. T.; Dozier, W. A.; Pharr, G. T. and Koutsos, E. A. 2007. Dietary threonine needs for growth and immunity of broilers raised under different litter conditions. Journal of Applied Poultry Research 16:574-582.

Duarte, K. F.; Junqueira, O. M.; Filardi, R. S.; Siqueira, J. C.; Garcia, E. A. and Laurentiz, A. C. 2012. Exigências em treonina para frangos de corte de 22 a 42 dias de idade. Revista Brasileira de Zootecnia 41:72-79.

Eftekhari, A.; Rezaeipour, V. and Abdullahpour, R. 2015. Effects of acidified drinking water on performance, carcass, immune response, jejunum morphology, and microbiota activity of broiler chickens fed diets containing graded levels of threonine. Livestock Science 180:158-163.

Ferreira, D. F. 2011. Sisvar - a computer statistical analysis system. Ciência e Agrotecnologia 35:1039-1042.

Ganzer, C.; Sierget, W.; Kluth, H.; Bennewitz, J. and Rodehutscord, M. 2017. Prececal amino acid digestibility of soybean cake in fast and slow-growing broiler chickens. Poultry Science 96:2804-2810.

Hamard, A.; Sève, B. N. and Le Floc'h, N. 2007. Intestinal development and growth performance of early-weaned piglets fed a lowthreonine diet. Animal 1:1134-1142.

Horn, N. L.; Donkin, S. S.; Applegate, T. J. and Adeola, O. 2009. Intestinal mucin dynamics: response of broiler chicks and White Pekin ducklings to dietary threonine. Poultry Science 88:1906-1914.

Jazideh, F.; Farhoomand, P.; Daneshyar, M. and Najafi, G. 2014. The effects of dietary glutamine supplementation on growth performance and intestinal morphology of broiler chickens reared under hot conditions. Turkish Journal of Veterinary and Animal $38: 264-270$.

Kim, D. H.; Brunt, J. and Austin, B. 2007. Microbial diversity of intestinal contents and mucus in rainbow trout (Oncorhynchus mykiss). Journal of Applied Microbiology 102:1654-1664.

Li, P.; Yin, Y.; Li, D.; Kim, S. W. and Wu, G. 2007. Amino acids and immune function: review article. British Journal of Nutrition 98:237-252.

Mehri, M.; Nassiri-Moghaddam, H.; Kermanshahi, H. and DaneshMesgaran, M. 2010. Digestible threonine needs of straightsrum broiler during the growing period. Jornual of Animal and Veterinary Advances 9:2190-2193.

Miranda, R. L.; Silva, F. O. C.; Lima, J. C. S.; Castro, J. R.; Quirino, R. C.; Severino, R. S. and Drummond, S. S. 2005. Origem e distribuição da artéria celíaca em aves (Gallus gallus) de corte da linhagem RedBro Plumé. Bioscience Journal 21:77-83.

Najafi, R.; Ahmar, R. and Tezehkand, G. N. 2017. Effect of different dietary threonine levels on optimal growth performance and intestinal morphology in 1-14 days old Ross 308 broilers. Brazilian Journal of Poultry Science Special Issue Nutrition:59-66.

NRC - National Research Council. 1994. Nutrient requirements of poultry. 9th rev. ed. National Academy Press, Washington, DC.

Ospinas-Rojas, I.C.; Murakami, A. E.; Oliveira, C. A. L. and Guerra, A. F. Q. G. 2013. Supplemental glycine and threonine effects on performance, intestinal mucosa development, and nutrient utilization of growing broiler chickens. Poultry Science 92:2724-2731.

Pinheiro, S. R. F.; Sakomura, N. K.; Nascimento, D. C. N.; Dourado, L. R. B.; Fernandes, J. B. K. and Thomaz, M. C. 2011a. Níveis nutricionais de fósforo disponível para aves de corte ISA Label criadas em semiconfinamento. Revista Brasileira de Zootecnia 40:361-369.

Pinheiro, S. R. F.; Sakomura, N. K.; Siqueira, J. C.; Marcato, S. M.; Dourado, L. R. B.; Fernandes, J. B. K. and Malheiros, E. B. 2011 b. Níveis nutricionais de cálcio para aves de corte ISA Label criadas sob semiconfinamento. Arquivo Brasileiro de Medicina Veterinária e Zootecnia 63:231-238.

Rezaeipour, V. and Gazani, S. 2014. Effects of feed form and feed particle size with dietary L-threonine supplementation on performance, carcass characteristics and blood biochemical parameters of broiler chickens. Journal of Animal Science and Technology 56:20.

Rezaeipour, V.; Foroni, H. and Irani, M. 2012. Effects of dietary L-threonine and Saccharomyces cerevisiae on performance, intestinal morphology and immune response of broiler chickens. South African Journal of Animal Science 42:266-273.

Rostagno, H. S.; Albino, L. F. T.; Donzele, J. L.; Gomes, P. C.; Oliveira, R. F.; Lopes, D. C.; Ferreira, A. S.; Barreto, S. L. T. and Euclides, R. F. 2011. Brazilian tables for poultry and swine: Composition of feedstuffs and nutritional requirements. 2nd ed. UFV, Viçosa, MG.

Sadrzadeh, A.; Hassanpour, H.; Mehrae-Hamzekolaei, M. H.; Farhadniya, P.; Ehsan, M. R. and Tohidi, F. S. S. 2015. Effects of post-hatch nutrition of arginine, lysine, methionine and threonine on performance and intestinal morphology in broiler chickens. Bulgarian Journal of Veterinary Medicine 18:294-303.

Sandberg, F. B.; Emmans, G. C. and Kyriazakis, I. 2007. The effects of pathogen challenges on the performance of naïve and immune animals: the problem of prediction. Animal 1:67-86.

Schaart, M. W.; Schierbeek, H.; Van Der Schoor, S. R. D.; Stoll, B.; Burrin, D. G.; Reeds, P. G. and Van Goudoever, J. B. 2005. Threonine utilization is high in the intestine of piglets. The Journal of Nutrition 135:765-770. 
Smirnov, A.; Tako, E.; Ferket, P. R. and Uni, Z. 2006. Mucin gene expression and mucin content in the chicken intestinal goblet cells are affected by in ovo feeding of carbohydrates. Poultry Science 85:669-673.

Toledo, A. L.; Taeara, P.; Bittecourt, L. C.; Kobashigawa, E.; Albuquerque, E. and Trindade Neto, M. A. 2007. Níveis dietéticos de lisina digestível para frangos de corte machos no período de
1 a 11 dias de idade: desempenho e composição corporal. Revista Brasileira de Zootecnia 36:1090-1096.

Zaefarian, F.; Zaghari, M. and Shivazad, M. 2008. The threonine requeriments and its effects on growth performance and gut morphology of broiler chicken fed different levels of protein. International Journal of Poultry Science 7:1207-1215. 